\title{
Spruce and birch growth in pure and mixed stands in Sweden
}

\author{
by Lars Lundqvist ${ }^{1}$, Tommy Mörling ${ }^{1}$ and Erik Valinger ${ }^{1, *}$
}

\begin{abstract}
An experiment was established in a 38-year-old, mixed species stand with a 14.5-m birch overstory (Betula species) and a 3-m spruce understory (Picea abies). Treatments were birch shelterwood with 300 or 600 stems/ha and spruce understory with 1500 stems/ha, grown separately or mixed on 14 plots. Height growth of spruce was not significantly affected by birch shelterwood during a 36-year observation period, but spruce trees under birch shelter were more slender. Volume growth of spruce was slightly reduced by birch shelter, and volume growth of birch significantly reduced by a spruce understory. Total growth was higher for mixed than for single-species plots.
\end{abstract}

Keywords: Betula pendula, Betula pubescens, competition, growth and yield, mixed species, Picea abies, shelterwood, stand structure, stem taper

\section{RÉSUMÉ}

Cet article porte sur un essai réalisé dans un peuplement mixte de 38 ans formé d'une strate dominante de bouleau (Betula spp.) de 14,5 m et d'un sous-étage dépinette (Picea abies) de $3 \mathrm{~m}$. Les traitements consistaient en une coupe progressive du bouleau à des densités de 300 ou 600 tiges/ha avec un sous-étage dépinette de 1500 tiges /ha croissant en peuplements purs ou mixtes dans 14 parcelles. La croissance en hauteur de lépinette na pas été affectée par la coupe progressive du bouleau au cours de la période de 36 ans couverte par létude, mais les épinettes en sous-étage des bouleaux affichaient de plus petits diamètres. La croissance en volume de lépinette a été légèrement réduite en présence de la strate dominant de bouleau et la croissance du bouleau a été considérablement réduite par la présence d'un sous-étage dépinette. La croissance totale était plus élevée dans les parcelles mixtes que dans celles ne comptant qu'une seule essence.

Mots clés : Betula pendula, Betula pubescens, compétition, croissance et rendement, essences mixtes, Picea abies, coupe progressive, structure du peuplement, défilement de la tige

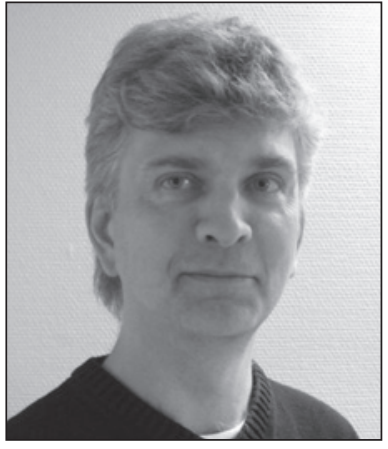

Lars Lundqvist

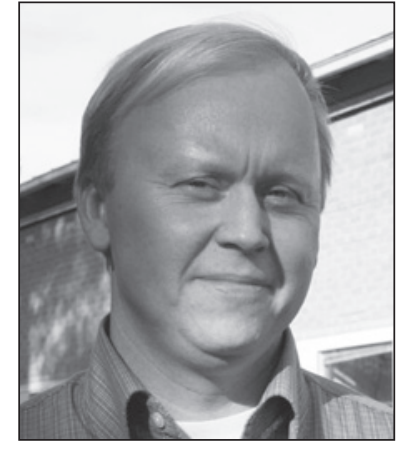

Tommy Mörling

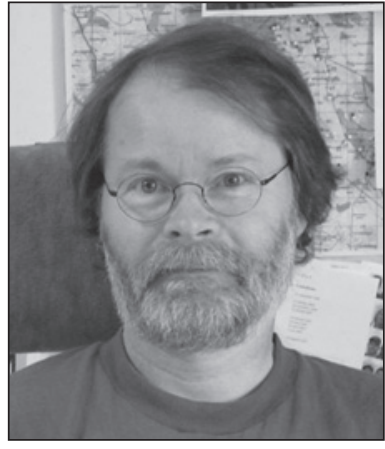

Erik Valinger

both species grow as they would have done if grown separately, i.e., they grow independently of each other. Finally, one or both species grow better together than when grown alone, i.e., a true mixing effect. There are basically two different ways of mixing species (Pretzsch 2009). The first is through tree replacement. The total stem number is not changed, i.e., a certain number of trees of species $\mathrm{X}$ are replaced by an equal number of trees of

\section{Introduction}

In the current debate about forest management, mixed species stands are often suggested as being more favourable for biodiversity (e.g., Bergeron and Harvey 1997, Xavier et al. 2011). It has also been suggested that mixed species stands should give higher volume growth than stands with just one species, i.e., monocultures, and several possible hypotheses have been presented. One of them, suggested by simulations and observation in field experiments, is that a positive mixing effect could result from utilization of different ecological niches (Pretzsch 2009). When two species are mixed, there can be one of three outcomes in terms of productivity. First, one or both species grow less than when grown alone, i.e., a competition effect. Secondly, species Y. The second is by adding a number of trees of species $\mathrm{Y}$ to a stand with species $\mathrm{X}$, i.e., increasing the total number of trees. In the second alternative a correct analysis should consider the resulting effect of this increase in stem number.

Marginally positive effects from sites with mixtures of Scots pine (Pinus sylvestris L.) and Norway spruce (Picea abies [L.] H. Karst.) have been presented by Jonsson (2001), and for Scots pine and silver birch (Betula pendula Roth) by, e.g., Mielikäinen (1981). In Scandinavia mixed-species stands of birch (Betula pendula Roth and Betula pubescens Ehrh.) and Norway spruce are quite common, since an abundant natural regeneration of initially fast-growing birch often invade clearcut areas and

\footnotetext{
${ }^{1}$ Swedish University of Agricultural Sciences, Department of Forest Ecology and Management. SE-901 83 Sweden.

*Corresponding author. E-mail: erik.valinger@slu.se
} 
overgrow planted, sown or naturally regenerated spruce with slower early growth. However, studies on total volume growth from mixtures of those species are inconclusive. In Scandinavian conditions Tham (1988) and Bergqvist (1999) report additive effects, while Frivold and Frank (2002) show no effect on spruce growth in 20 mixed stands compared with adjacent pure conifer stands. In Canada Légaré et al. (2004) show a positive effect of aspen (Populus tremuloides Michx.) on black spruce (Picea mariana [Mill.] BSP) when mixed. Similar to Pretzsch (2009), they (Légaré et al. 2004) suggest that the two mixed species use different niches.

In northern Sweden Scots pine is considered more productive than Norway spruce while birch is least productive (Ekö et al. 2008), but mixing birch and spruce is considered favourable for total growth (Tham 1988). Birch has fast development during the establishment phase and short rotation, whereas spruce has slow initial development but longer rotation. Regenerating under shelterwoods could be a means of not only attaining high growth but also of establishing trees with an economically favourable stem form (Krasowski and Wang 2003). Several experiments have shown that stem taper is highly dependent on differences in spacing (e.g., Bergqvist 1999, Deans and Milne 1999). It has also been shown that wind sway has a profound effect on stem taper (e.g., Valinger 1992a, Brüchert and Gardiner 2006). Trees growing under a shelterwood can thus be expected to experience less mechanical wind load compared to openly grown trees, and should therefore be expected to have more slender stems.

In the present study we examined (i) the change in growth of Norway spruce caused by presence of a birch overstory, and (ii) the change in volume growth of birches caused by presence of a Norway spruce understory during 36 years after experiment establishment. The overall hypothesis was that a mixture of the species would result in a lower-volume yield for each of the species separately but a gain in total growth. Furthermore, we hypothesized that the height:diameter ratio would be significantly higher for spruce grown under sheltered conditions compared with spruces grown without a shelter.

\section{Material and Methods}

The experiment was established in 1973 to 1975 north of Vindeln in Northern Sweden (Lat. 64 $18^{\prime} 30^{\prime \prime} \mathrm{N}$, Long. 1944'55"E) on a flat, mesic-moist site at altitude $260 \mathrm{~m}$. Site index according to site factors (Hägglund and Lundmark 1987) was G18, i.e., an expected top height of Norway spruce at 100 years of age was $18 \mathrm{~m}$. The area was clear-felled in 1930. After prescribed burning, the area was regenerated by direct seeding with a mix of Scots pine and Norway spruce seeds of local provenance in 1938. A dense regeneration of birch (silver birch, Betula pendula Roth and downy birch, Betula pubescens Ehrh.) appeared spontaneously. Precommercial thinning of birch was done in 1951. In the early 1970s, before experiment establishment, the number of birches was about 1900 stems/ha, with top height about $15 \mathrm{~m}$, and standing volume about $130 \mathrm{~m}^{3} \mathrm{ha}^{-1}$. The stem number of the two birch species was almost equal but the silver birches were larger than the downy and $\mathrm{SB} 6=\mathrm{S}+\mathrm{B} 6$ birches. There were about 3000 stems/ha of Norway spruce beneath the birches with a mean height of about $3 \mathrm{~m}$.

The experiment comprised 14 plots of 0.1 ha, grouped in seven pairs of plots with contrasting treatments. Each plot was surrounded by a 5- to 10-m wide buffer zone with the same treatment as the net plot. The treatments randomly allotted were dense $(\mathrm{B} 6=600 \mathrm{birch}$ stems $/ \mathrm{ha})$, sparse $(\mathrm{B} 3=300$ birch stems/ha) or no birch shelterwood, combined with no (zero) or 1500 stems/ha spruce understorey (S), resulting in a total of five combinations: B6, B3, SB6, SB3, S. Volume before establishment did not differ between the treatments, but the standing volume after treatment differed between the two shelter densities (Table 1).

Three plot-pairs with the combination S/SB6 were established in the last week of July 1973 and the remaining four plot-pairs (S/SB3, SB6/SB3, B6/B3, B6/B3) in September 1975. The shelters consisted almost entirely of silver birch but on three of the plots a few Scots pines were included in the shelters (1-10\% of the stem number). Despite this, the shelters were considered as birch shelters.

Following establishment in 1973/1975, re-measurements of the experiment were made in 1980, 1985, 1990, 1994, 2001, 2006, and 2011. At each measurement occasion all trees were cross-callipered at $1.3 \mathrm{~m}(\mathrm{DBH})$ to the nearest $\mathrm{mm}$. Total height was measured to the nearest $0.1 \mathrm{~m}$ on 20 sample trees per species and plot, randomly selected among living, undamaged trees of all species. However, only birch was measured at establishment. Spruces were not measured until the first remeasurement, in 1980.

The stem taper of open-grown and sheltered spruces was expressed by the height:diameter ratio (h:d), where $h$ is basal area weighed mean height $(\mathrm{m})$ and $\mathrm{d}$ is the quadratic mean diameter (cm) on each treatment plot.

Stem volumes above stump were calculated for sample trees with volume functions presented by Brandel (1990), and sample tree data was generalized to all trees by methods described by Nilsson et al. (2010).

The experiment was unbalanced, i.e., the number of replicates differed between treatments, such that there were two replicates for all treatments except S and SB6, which had four replicates (Table 1). The statistical evaluation was performed using SAS GLM, testing four different response variables: spruce height growth, spruce height:diameter quotient, spruce volume growth and birch volume growth. The response variables were modelled as functions of different combinations of $\mathrm{V}_{\text {before }}$ (total standing volume per plot before treatment), and dummy

Table 1. Data at experiment establishment

\begin{tabular}{lccc}
\hline Treatment & $\begin{array}{c}\text { Number of } \\
\text { replicates }\end{array}$ & $\begin{array}{c}\text { Standing volume before } \\
\text { plot establishment } \\
\left(\mathbf{m}^{\mathbf{3}} \cdot \mathbf{h a}^{-\mathbf{}}\right)\end{array}$ & $\begin{array}{c}\text { Standing volume after } \\
\text { treatment in 1973/1975 } \\
\left(\mathbf{m}^{\mathbf{3}} \cdot \mathbf{h a}^{-1}\right)\end{array}$ \\
\hline S & 4 & $133.8 \mathrm{a}^{\mathrm{b}}$ & - \\
B3 & 2 & $114.1 \mathrm{a}$ & $39.1 \mathrm{a}$ \\
SB3 & 2 & $125.6 \mathrm{a}$ & $40.2 \mathrm{a}$ \\
B6 & 2 & $118.4 \mathrm{a}$ & $65.3 \mathrm{~b}$ \\
SB6 & 4 & $146.0 \mathrm{a}$ & $68.4 \mathrm{~b}$ \\
\hline
\end{tabular}

a $\mathrm{S}=$ spruce understory (1 500 spruce stems $/ \mathrm{ha}), \mathrm{B} 3=300 \mathrm{birch}$ stems $/ \mathrm{ha}, \mathrm{B} 6=600 \mathrm{birch}$ stems $/ \mathrm{ha}, \mathrm{SB} 3=\mathrm{S}+\mathrm{B} 3$,

${ }^{\mathrm{b}}$ Data in the same column not followed by the same letter are significantly different $(P<0.05)$ 
variables for presence of spruce undergrowth (S) or birch shelter (one single dummy variable (B) or two dummy variables with shelter effect split on sparse (B3) and dense (B6) shelters).

Differences and effects were regarded as significant if $P<0.05$. All analyses were executed using SAS Statistical Package (GLM; SAS Institute Inc. 1987).

\section{Results}

Mortality was low during the observation period. Only 5\% of the shelter trees and 3\% of the understory spruces died in the 36 -year observation period. In 1980, the mean height of spruce was $5.2 \mathrm{~m}$ and that of birch $15.2 \mathrm{~m}$. In autumn 2011, the mean height of spruce was in average $13.0 \mathrm{~m}$ and of birch $20.3 \mathrm{~m}$.

There were no significant differences in mean height between treatments for neither spruce (Fig. 1) nor birch (not shown) in 1980 and $2011(P>0.05)$. Spruce mean height in 2011 was, however, positively correlated with total standing volume before treatment, $\mathrm{V}_{\text {before }}(P=0.021)$.

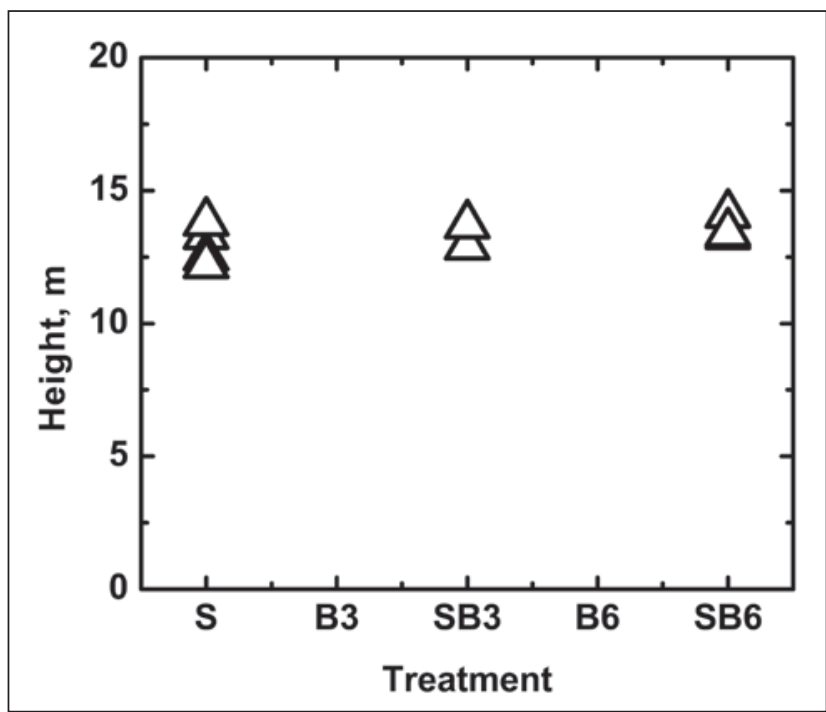

Fig. 1. Mean height (m) of Norway spruce in 2011. For abbreviations see Table 1.

Height: diameter ratio of Norway spruce increased throughout the observation period, and spruces growing under birch shelter had a significantly higher height:diameter ratio, i.e., smaller diameter at a given height (Table 2).

Table 2. Mean height:diameter ratio $(\mathrm{m} / \mathrm{cm})$ of Norway spruce at the different measurement years

\begin{tabular}{ccccc}
\hline & \multicolumn{3}{c}{ Treatment $^{\mathrm{a}}$} \\
Year & $\mathbf{S}$ & SB3 & SB6 & P-value \\
\hline 1985 & $0.84 \mathrm{a}^{\mathrm{b}}$ & $0.93 \mathrm{~b}$ & $0.93 \mathrm{~b}$ & 0.0146 \\
1990 & $0.83 \mathrm{a}$ & $0.88 \mathrm{a}$ & $0.95 \mathrm{~b}$ & 0.0015 \\
1994 & $0.84 \mathrm{a}$ & $0.91 \mathrm{~b}$ & $0.98 \mathrm{~b}$ & 0.0005 \\
2001 & $0.85 \mathrm{a}$ & $0.93 \mathrm{a}$ & $1.02 \mathrm{~b}$ & 0.0004 \\
2006 & $0.88 \mathrm{a}$ & $0.99 \mathrm{~b}$ & $1.02 \mathrm{~b}$ & 0.0004 \\
2011 & $0.92 \mathrm{a}$ & $1.04 \mathrm{~b}$ & $1.07 \mathrm{~b}$ & 0.0022 \\
\hline
\end{tabular}

${ }^{\text {a }}$ For abbreviations see Table 1

${ }^{\mathrm{b}}$ Data in the same row not followed by the same letter are significantly different $(P<0.05)$
Total volume growth for spruce $(\mathrm{S})$ with no birch shelter up to 2011 was about $126 \mathrm{~m}^{3} \cdot \mathrm{ha}^{-1}$ (Fig. 2), while growth for the sparse birch shelter (B3) was about $81 \mathrm{~m}^{3} \cdot \mathrm{ha}^{-1}$ and for the dense shelter (B6) about $126 \mathrm{~m}^{3} \cdot \mathrm{ha}^{-1}$ in the period 1973/1975 to 2011 (Fig. 3). The combination of spruce and birch shelter resulted in a total growth during the experimental period of about 183 $\mathrm{m}^{3} \cdot \mathrm{ha}^{-1}$ with the sparse shelter (SB3) and $242 \mathrm{~m}^{3} \cdot \mathrm{ha}^{-1}$ with the dense shelter (SB6).

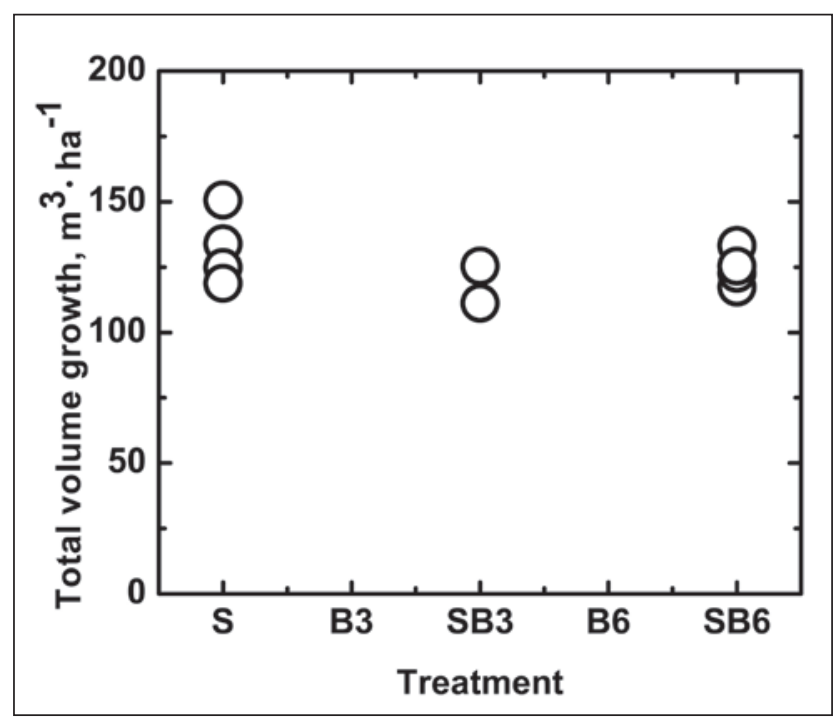

Fig. 2. Total growth of Norway spruce $\left(\mathrm{m}^{3} \cdot \mathrm{ha}^{-1}\right)$ from 1938 to 2011. For abbreviations see Table 1.

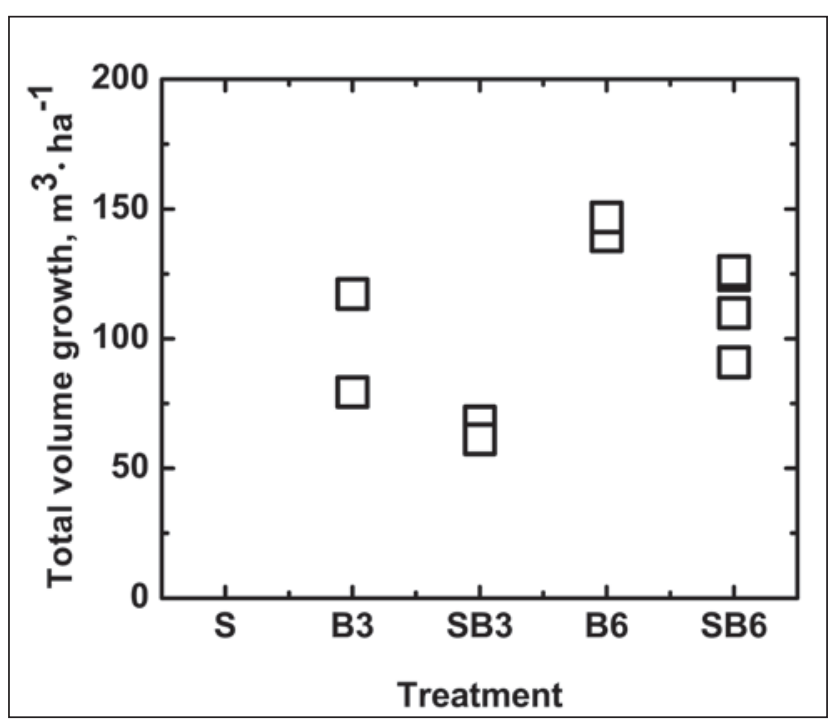

Fig. 3. Total growth of birch $\left(\mathrm{m}^{3} \cdot \mathrm{ha}^{-1}\right)$ from plot establishment in 1973/1975 until 2011. For abbreviations see Table 1.

There was no statistically significant difference in total volume growth of Norway spruce during the observation period between plots with and without birch shelter (B), but when including standing volume before treatment $\left(\mathrm{V}_{\text {before }}\right)$ as covariate a significant difference appeared (Table 3 ). When shelter 
influence was split into the two shelter densities (B3, B6) none of the variables was significant, but the denser shelter (B6) indicated slightly larger reduction than the sparser (B3).

The total volume growth of birch was significantly lower with an understory of spruce present (Table 4).

Annual volume increment of spruce increased during the observation period and was $5.5 \mathrm{~m}^{3} \cdot \mathrm{ha}^{-1} \cdot \mathrm{year}^{-1}$ in the last five-year period (Fig. 4). For birch there was no similar trend. Current volume increment varied around $3.0 \mathrm{~m}^{3} \cdot \mathrm{ha}^{-1} \cdot \mathrm{year}^{-1}$.

Table 3. Spruce growth $\left[\mathrm{V}_{\mathrm{s}}\right.$ ) as effected by standing volume before treatment $\left(\mathrm{V}_{\text {before }}\right.$ ) and birch shelter ( $\mathrm{B}$ or $\mathrm{B} 3$ and $\mathrm{B} 6$ )

\begin{tabular}{lcccc}
\hline Model & Variable & Coefficient & Stand. error & $\boldsymbol{P}$-value \\
\hline A & Constant & 132.0 & - & - \\
& B & -9.85 & 6.66 & 0.177 \\
B & & & & \\
& Constant & 78.6 & - & - \\
& $\mathrm{V}_{\text {before }}$ & 0.399 & 0.125 & 0.015 \\
& B & -12.0 & 4.59 & 0.035 \\
C & & & & \\
& Constant & 75.5 & - & - \\
& V & 0.422 & 0.146 & 0.028 \\
& B3 3 & -10.3 & 6.61 & 0.171 \\
& B6 & -13.0 & 5.60 & 0.059 \\
\hline
\end{tabular}

Table 4. Birch growth as effected by spruce understory (S) and shelter density [B3]

\begin{tabular}{lccc}
\hline Variable & Coefficient & Standard error & $\boldsymbol{P}$-value \\
\hline Constant & 138.8 & & \\
S & -28.1 & 10.3 & 0.029 \\
B3 & -46.4 & 10.3 & 0.003 \\
\hline
\end{tabular}

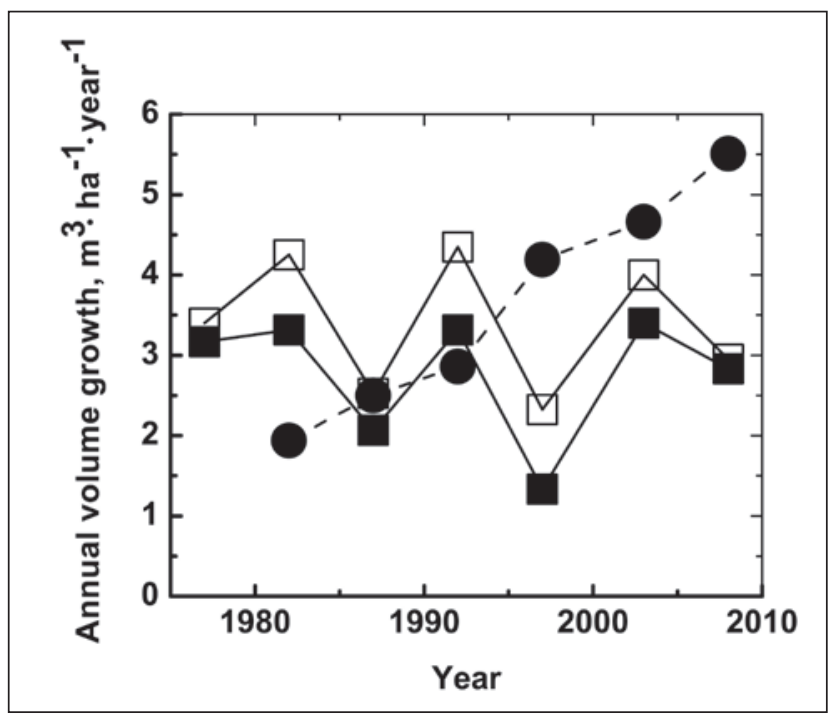

Fig. 4. Annual growth $\left(\mathrm{m}^{3} \cdot \mathrm{ha}^{-1} \cdot\right.$ year $\left.^{-1}\right)$ from 1977 to 2008. Circles $=$ spruce, Open squares $=$ birch without spruce understory, Filled squares $=$ birch with spruce understory.

\section{Discussion}

The experiment had two major weaknesses that might have affected the results. The first was the different number of replicates for the treatments, i.e., the experiment was unbalanced, and the second was the presence of pines on three of the plots with spruce understory. The unbalance was dealt with by analyzing the experiment with the SAS GLM procedure for unbalanced data (SAS Institute Inc. 1987), hence eliminating this problem.

Presence of pines was deemed not to have affected the conclusions. Since Scots pine have a higher growth rate than both birch species, presence of pines could have affected the results in two ways. First, the pines could be expected to have exerted higher competition on the spruces than an equal number of birches, i.e., have increased the competitive effect of the overstory. Secondly, the pines most likely increased the growth of the shelterwood. In both cases the pines would have counteracted the results observed. If the pines had been replaced by an equal number of birches from start, the results would, most likely, have been even clearer.

The low mortality during the whole observation period, especially in the spruce understory, strengthens the conclusion on low competition from the birch shelter. The spruces have grown almost $8 \mathrm{~m}$ in 31 years, indicating an expected top height of 22 $\mathrm{m}$ for Norway spruce at 100 years of age (site index G22 in the Swedish system) according to equations by Elfving and Kiviste (1997). That is considerably taller than the $18 \mathrm{~m}$ estimated from site factors according to Hägglund and Lundmark (1987), in spite of growing under a shelter.

In the analyses of spruce growth, the significant influence of the variable $V_{\text {before }}$ (volume before treatment) can be interpreted as an indirect measure of site productivity of the different plots. However, lack of significant influence of $\mathrm{V}_{\text {before }}$ on spruce mean height in 1980 is in contrast to this conclusion.

The influence of the birch shelter on spruce was lower in our evaluation compared to Bergqvist's (1999) analyses of the early development in this field experiment. Our observations, furthermore, did not correspond with observations in several other studies, showing an increasingly negative influence of an aspen shelter with increasing basal area on understory white spruce (Picea glauca [Moench] Voss) growth (e.g., Filipescu and Comeau 2007), and of a paper birch (Betula papyrifera Marsh.) shelter on an understory of young subalpine fir (Abies lasiocarpa [Hook.] Nutt.) and white spruce (Comeau et al. 2003). This supports the opinion that the mixing effect differs between species, site conditions and over age (Frivold and Frank 2002, Pretzsch 2009, Pretzsch et al. 2010).

The highly significant influence of the birch shelter on spruce height:diameter ratio can be interpreted in two ways: as a density effect, and as a biomechanical effect. The density effect interpretation was supported by the ratio decreasing over the years (cf. Bokalo et al. 2007). A similar effect on taper was found for shaded spruce trees (Assman 1970), after different release cuts of understory subalpine fir (Comeau et al. 2003, Krasowski and Wang 2003) and in un-thinned stands of Scots pine as they grow taller during a five year period (Valinger 1992b). The second interpretation, as a biomechanical effect, is based on studies showing that diameter growth is strongly affected by wind sway (e.g., Brüchert and Gardiner 2006). Spruces growing under birch shelter can be expected to receive less wind load, and as a consequence less wind sway, which would explain the more slender stems under the shelter. Increased wind load can result 
not only in increased diameter growth, but also in reduced height growth, as reported for lodgepole pine (Pinus contorta Dougl.) by Meng et al. (2006). The unsheltered spruces could thus have had lower height growth than the spruces grown under the birch shelter. However, increased competition can also result in reduced height growth as indicated for white spruce and subalpine fir by Comeau et al. (2003). The lack of significant difference in height development between the different treatments in this study could thus be an effect of opposing reactions to competition and mechanical load.

We have no good explanation of why growth of birch was reduced more than the growth of spruce, but similar results have been found in pine stands with undergrowth of spruce, where the growth of the pine overstory was reduced by the undergrowth (Isomäki 1979, Haveraaen 1981).

Total growth on the mixed species plots being higher than that of the pure birch and spruce stands was in accordance with studies by Tham (1988) and Pretzsch (2009). The overall hypothesis, that mixing of the species would result in a higher volume growth, was thus confirmed. However, the growth on the mixed plots was in fact lower than the sum of the pure spruce plots and corresponding pure birch shelter plots, indicating that the positive effect was to a large degree only an additive effect of higher stem number. The lack of shelter influence on spruce height development means that if the birch shelter is removed in the near future, both sheltered and non-sheltered spruces can be expected to have similar future height development. The differences in height:diameter ratio observed so far can be expected to disappear when the spruces grow under similar conditions, resulting in similar volume growth at the end of the rotation. This means that the growth of birch in a shelterwood system of the kind presented here would be a sheer additive growth, seen from a practical point of view. However, the regeneration period had been prolonged due to reasons unknown. When the first plots were established in 1973, 35 years had passed since the area had originally been regenerated. From a scientific point of view the growth of the mixed stand should really be compared with a pure spruce regeneration starting in 1938, which would thus have been 73 years old in 2011. According to growth tables published by Ericsson (1976), a spruce stand with similar stem number on a G22 site, as estimated from spruce height development, should have yielded about $350 \mathrm{~m}^{3} \cdot \mathrm{ha}^{-1}$ during 73 years.

Lack of trend for birch in annual volume increment indicates that the birch shelters can be expected to continue with a fairly high growth rate for several years to come. The large variation between periods could be a result of systematic differences between field personnel in height measurement between measurements. Height measurement on birch is sensitive to how the top is distinguished and how close the tip is to the centre of the vertical stem axis. Since height growth is slow, small systematic differences in the measurement procedure cause big variation in estimation of height and volume growth.

A shelterwood can have a large impact on the development of regeneration in areas with harsh climate. An overstory can enhance seedling survival of a secondary species by reducing frost damage (Groot and Carlson 1996, Ottosson-Löfvenius 1998, Filipescu and Comeau 2011), or by reducing competition from herbaceous species (Lieffers and Stadt 1994). It has been shown that the difference in minimum nighttime temperature between a shelterwood and a clearcut area increases with the number of stems per hectare in the shelter, and by the height of the shelter trees (Ottosson-Löfvenius 1998). Other subject areas of interest in mixed species stands that have evolved since late 1980s are e.g., increased considerations to biodiversity issues (e.g., Bergeron and Harvey 1997, Man et al. 2010, Xavier et al. 2011) and wind stability (e.g., Valinger and Fridman 2011).

In conclusion, regenerating spruce under an overstory of birch up to a shelter density of around 600 stems/ha, show a potential to produce a rotation of birch growth without or with small losses in growth of the spruce in circumstances where a birch shelter appear spontaneously.

\section{References}

Assman, E. 1970. The principles of forest yield study. Pergamon Press, Oxford. $506 \mathrm{p}$.

Bergeron, Y. and B. Harvey. 1997. Basing silviculture on natural ecosystem dynamics: an approach applied to the southern boreal mixedwood forest of Quebec. For. Ecol. Manage. 92: 235-242.

Bergqvist, G. 1999. Wood volume yield and stand structure in Norway spruce understorey depending on birch shelterwood density. For. Ecol. Manage. 122: 221-229.

Bokalo, M., P.G. Comeau and S.J. Titus. 2007. Early development of tended mixtures of aspen and spruce in western Canadian boreal forests. For. Ecol. Manage. 242: 175-184.

Brandel, G. 1990. Volume functions for individual trees : Scots pine (Pinus sylvestris), Norway spruce (Picea abies) and birch (Betula pendula \& Betula pubescens). Swedish University of Agricultural Sciences, Department of Forest Yield Research, Garpenberg. ISBN 91-576-4030-0.

Brüchert, F. and B. Gardiner. 2006. The effect of wind exposure on the tree aerial architecture and biomechanics of Sitka spruce (Picea sitchensis, Pinaceae). Am. J. Bot. 93 (10): 1512-1521.

Comeau, P.G., J.R. Wang and T. Letchford. 2003. Influences of paper birch competition on growth of understory white spruce and subalpine fir following spacing. Can. J. For. Res. 33: 1962-1973. Deans, J.D. and R. Milne. 1999. Effects of respacing on young Sitka spruce crops. Forestry 72 (1): 47-57.

Ekö, P.-M., U. Johansson, N. Pettersson, J. Bergqvist, B. Elfving and J. Frisk. 2008. Current growth differences of Norway spruce (Picea abies), Scots pine (Pinus sylvestris) and birch (Betula pendula and Betula pubescens) in different regions in Sweden. Scand. J. For. Res. 23: 307-318. Elfving, B. and A. Kiviste. 1997. Construction of site index equations for Pinus sylvestris L. using permanent plot data in Sweden. For. Ecol. Manage. 98: 125-134.

Eriksson, H. 1976. Granens produktion i Sverige [Yield of Norway spruce in Sweden]. Royal College of Forestry, Dept of Forest Yield Research, Rapporter och uppsatser [Research notes] nr 41. (In Swedish with English summary.)

Filipescu, C.N. and P.G. Comeau. 2007. Competitive interactions between aspen and white spruce vary with stand age in boreal mixedwoods. For. Ecol. Manage. 247: 175-184. Filipescu, C. N. and P.G. Comeau. 2011. Influence of Populus tremuloides density on air and soil temperature. Scand. J. For. Res. 26: 421-428. Frivold, L-H. and J. Frank. 2002. Growth of Mixed Birch-Coniferous Stands in Relation to Pure Coniferous Stands at Similar Sites in Southeastern Norway. Scand. J. For. Res. 17: 139-149.

Groot, A. and D.W. Carlson. 1996. Influence of shelter on night temperatures, frost damage, and bud break of white spruce seedlings. Can. J. For. Res. 26: 1531-1538.

Hägglund, B. and J.-E. Lundmark. 1987. Handledning i bonitering med Skogshögskolans boniteringssystem. Del 1 Definitioner och anvisningar. Skogsstyrelsen. (In Swedish.)

Haveraaen, O. 1981. Growth of Scots pine after clearing of Norway spruce underwood. Rapp. Nor. Inst. Skogforsk. 9/81: 1-20. Isomäki, A. 1979. The effect of spruce undergrowth on the increment, yield and returns of a pine stand. Folia For. 392.

Jonsson, B. 2001. Volume yield to mid-rotation in pure and mixed sown stands of Pinus sylvestris and Picea abies in Sweden. Stud. For. Suec. 211. 
Krasowski, M.J. and J.R. Wang. 2003. Aboveground growth responses of understory Abies lasiocarpa saplings to different release cuts. Can. J. For. Res. 33: 1593-1601.

Légaré, S., D. Paré and Y. Bergeron. 2004. The responses of black spruce growth to an increased proportion of aspen in mixed stands. Can. J. For. Res. 34: 405-416.

Lieffers, V.J. and K.J. Stadt. 1994. Growth of understory Picea glauca, Calamagrostis canadensis, and Epilobium angustifolium in relation to overstory light. Can. J. For. Res. 24: 1193-1198.

Man, R., J.A. Rice and G.B. MacDonald. 2010. Five-year light, vegetation, and regeneration dynamics of boreal mixedwoods following silvicultural treatments to establish productive aspen-spruce mixtures in northeastern Ontario. Can. J. For. Res. 40: 1529-1541.

Meng, S.X., V.J. Lieffers, D.E.B. Reid, M. Rudnicki, U. Silins and M. Jin. 2006. Reducing stem bending increases the height growth of tall pines. J. Exp. Bot. 57 (12): 3175-3182.

Mielikäinen, K. 1981. Blandskogens produktion i östra Finland. Sver. Skogsvårdsförb.Tidskr. 79(6): 3-9. (In Swedish.)

Nilsson, U., E. Agestam, P.-M. Ekö, B. Elfving, N. Fahlvik, U. Johansson, K. Karlsson, T. Lundmark and C. Wallentin. 2010. Thinning of Scots pine and Norway spruce monocultures in Sweden: effects of different thinning programmes on stand level gross- and net stem volume production. Stud. For. Suec. 219.

Ottosson-Löfvenius, M. 1998. Temperature and radiation regimes in selective thinned forest stand. New stand types in boreal forestry. Metla, Research Papers 714: 29-32.
Pretzsch, H. 2009. Forest dynamics, growth and yield. Springer Verlag Pretzsch, H., J. Block, J. Dieler, P.H. Dong, U. Kohnle, J. Nagel, H. Spellmann and A. Zingg. 2010. Comparison between the productivity of pure and mixed stands of Norway spruce and European beech along an ecological gradient. Ann. For. Sci. 67: 712-712. doi: 10.1051/ forest/2010037.

SAS Institute Inc. 1987. SAS/STAT TM Guide for personal computers, version 6 edition. SAS Institute Inc., Cary, NC.

Tham, Å. 1988. Yield prediction after heavy thinning of birch in mixed stands of Norway spruce (Picea abies (L.) Karst.) and birch (Betula pendula Roth and Betula pubescens Ehrh.). Department of Forest Yield Research, Report No. 23. Swedish University of Agricultural Sciences. Garpenberg. ISBN 91-576-3514-5.

Valinger, E. 1992a. Effects of wind sway on stem form and crown development of Scots pine (Pinus sylvestris L.). Aust. For. 55: 15-21.

Valinger, E. 1992b. Effects of thinning and nitrogen fertilization on stem growth and stem form of Pinus sylvestris trees. Scand. J. For. Res. $7: 219-228$.

Valinger, E. and J. Fridman. 2011. Factors affecting the probability of windthrow at stand level as a result of Gudrun winter storm in southern Sweden. For. Ecol. Manage. 262: 398-403.

Xavier, C., S.E. Macdonald, Y. Bergeron and H.Y.H. Chenc. 2011. Importance of mixedwoods for biodiversity conservation: Evidence for understory plants, songbirds, soil fauna, and ectomycorrhizae in northern forests. Environ. Rev. 19: 142-161. 